\section{Value allocation to stakeholder employees and its effect on the competitiveness of the banking sector}

\author{
Isac de Freitas Brandáo \\ Andressa Silva Miranda Diógenes \\ Mônica Cavalcanti Sá de Abreu \\ Federal University of Ceará, Faculty of Economy, \\ Business and Accounting, Fortaleza, Ceará, Brazil
}

Received on

04/26/2016

Approved on

09/23/2016

Responsible editor:

$\mathrm{PhD}$. Leire San-Jose

Evaluation process:

Double Blind Review

\begin{abstract}
Purpose - This paper investigates the relationship between corporate social responsibility practices geared towards stakeholder employees and the competitiveness and productivity of Brazilian banks.

Design/methodology/approach - We carried out two association statistical analyses between the proxies of competitiveness and the variables that indicated of internal social responsibility: the JonckheereTerpstra test and regression analysis with Feasible Generalized Least Squares (FGLS) modeling. The sample is made up of 21 banks listed in BM\&FBovespa over the 2010-2014 period.
\end{abstract}

Findings - The survey shows that corporate social responsibility practices geared towards employees impact the financial performance of banks. Employees' salaries positively affected financial performance, and the latter was negatively affected by the rate of outsourcing, both explained by greater employee productivity. Employee turnover and female participation in management and governance bodies are directly related to competitiveness indicators, in a negative and positive way, respectively, with no regard to employee productivity.

Originality/value - Banks that offer better CSR practices to their employees present greater financial gains and increased employee productivity. There are specific items that have the potential to lead to a competitive status, adding value to businesses and employees. This research argues that managers should identify the CSR practices that add value to their companies and the benefits derived from value allocation to employees.

Keywords - Corporate social responsibility; stakeholders; competitiveness, banks, value allocation.

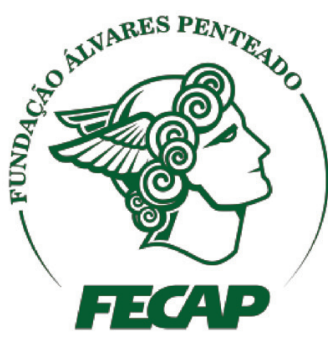

Review of Business Management

DOI: $10.7819 /$ rbgn.v0i0.3199 


\section{Introduction}

There is a multiple dependence relationship between companies and interested parties (stakeholders) in the process of raising funds and supplying goods and services. In this context, corporate social responsibility (CSR) is approached not only as a company's moral obligation to society, but also as a means of aligning the company's interests with those of its stakeholders so as to reduce hazards and ensure business continuity. CSR practices can be internal (i.e., geared towards employees), external (i.e., towards the external public - such as customers, government, and suppliers) - and environmental (i.e. towards environmental preservation) (Crisóstomo, Freire, \& Vasconcelos, 2011).

Amongst these dimensions, internal CSR is a primary vector for financial performance, since employees supply the workforce necessary to productive activities. The relationship between companies and their employees enhances satisfaction and motivation, which may reflect on a company's financial performance through its employees' greater productivity (Boaventura, 2012; Huselid, 1995; Huselid, Jackson, \& Schuler, 1997). In the banking sector, internal CSR is even more relevant to financial performance, and it may be a source of competitive advantages. Bartel (2004) suggests that direct contact between customers and employees in the service sector requires the extensive adoption of socially responsible practices.

Based on this analysis, the following object of research emerges: What is the relationship between the adoption of CSR practices geared towards stakeholder employees and the competitiveness of the Brazilian banking sector? This paper discusses value allocation to stakeholder employees through adoption of social responsibility practices and the competitive differential in the Brazilian banking sector, thus contributing to an increase in employees' productivity and to higher financial performance, contrary to the cost reduction policy and to the deterioration of working conditions for the sake of productivity gains.
Therefore, this paper starts from the assumption that the allocating value to stakeholder employees may yield gains in competitiveness. These gains derive from greater job satisfaction, productivity, and organizational commitment. Focus on competitiveness is geared towards its impact on financial performance indicators such as: efficiency, growth, and profitability (Hamel \& Prahalad, 1989). In this context, the study carried out by Brito \& Brito (2012) must be highlighted, since it proposes measurement of financial performance based on sales profitability and growth as a proxy of competitive advantage.

Since the relationship between CSR and competitiveness is not as yet totally clear, the question is in the identification of policies or strategies that are capable of developing CSR that strengthens competitiveness factors. Accordingly, this paper analyzes the relationship between corporate social responsibility practices geared towards employees and the competitiveness of Brazilian banks, explained by employees' higher productivity in companies that adopt better people management practices.

To achieve the goal proposed here, the following section presents the theoretical references which contemplate the influence of CSR practices geared towards stakeholder employees on organizational performance, and research hypotheses. Next, we present the methodology used when collecting data regarding the internal CSR of 21 banks whose shares are listed in BM\&FBovespa and their impact on the financial performance of those institutions over the 2010-2014 period. Finally, results are presented and discussed, followed by the final considerations to this study.

\section{Theoretical references}

\section{I The impact of corporate social responsibility and stakeholder management on competitiveness}

Competitiveness is a latent construct observed according to the position of a company in relation to its competitors (Brito \& Brito, 
2012). Vilanova, Lozano \& Arenas (2009) point out that the general notion of competitiveness is defined by the market, in that its critical factors are given in view of how financial analysts evaluate a given company. Ajitabh \& Momaya (2004) state that competitiveness can be categorized according to five fundamental dimensions: financial performance, in which profit and sales growth stand out (Hamel \& Prahalad, 1989); quality of products/services, which refer to satisfying consumers' needs (Barney, 2000); productivity, in terms of efficiency; innovation in products/ services or in the process of image management, in which trademarks are made evident in order to achieve a good reputation; and trust in the relationship with stakeholders (Kay, 1993).

Motivated by intense competitiveness in the market, companies began to assess their relationships with their stakeholders so as to empower these relationships - and, thus, gain competitive advantages, which involves appreciating and compensating cooperative, ethical, transparent behavior (Feitosa, Souza, \& Gómez, 2014). Garcia-Castro \& Aguilera (2015) emphasize the notion of stakeholders as any group or individuals who create and capture economic value in their interactions with the company.

Interested parties who are well treated tend to reciprocate with positive attitudes and behavior, thus making stakeholder management an efficient way of achieving competitive advantages (Harrison, Freeman, \& Abreu, 2015). According to Maloni \& Brown (2006), ethical, socially and environmentally responsible behavior can be perceived by many categories of stakeholders, such as customers, employees, governments, communities, investors, suppliers, government agencies, the press, and NGOs but, for this to occur, companies must internalize CSR principles.

CSR is companies' voluntary involvement in social and environmental matters, whilst maintaining the equilibrium of the organizations' activities and a good relationship with stakeholders (European Comission, 2002). The CSR approach can be understood from several perspectives, such as: a social development tool (Carroll,
1979; Swanson, 1995), a model of corporate ethics (Solomon, 1993), a way of exercising corporate governance (Freeman \& Evans, 1990), a model of social contract (Donaldson \& Dunfee, 2002), a corporate citizenship device (Waddock, 2000; Zadek, 2006), a model of accountability (Elkington, 1998), and a mechanism for stakeholder management (Donaldson \& Preston, 1995; Freeman, 1984; Lozano, 2002).

The instrumental view of the stakeholder theory led to an idea known as stakeholder management, which advocates that CSR practices will only be complete when they are totally absorbed by internal stakeholders, that is, employees (Feitosa, Souza, \& Gómez, 2014). Accordingly, socially responsible practices establish a set of ethical principles, such as trust, credibility, and cooperation, which enable competitive advantages to be achieved. Jones (1995) believes that managers who interact with their stakeholders on a mutual trust and cooperation basis will doubtless achieve competitive advantages.

Margolis \& Walsh (2003) point out that, when managers get to understand the instrumental aspect of CSR, socially and environmentally responsible practices naturally cease to be an obligation and become a means to achieve a company's strategic goals. Freeman, Harrison, Wicks, Parmar, \& De Colle (2010) also highlight the importance of corporate social responsibility to the maintenance of a good relationship with interested parties. Therefore, companies must measure their ability to respond efficiently to the public they interact with. Regarding this, social/ environmental reports may reveal how companies have been responding to certain demands by stakeholders.

Vilanova et al. (2009) point out that few companies adopt altruistic CSR. On the contrary, they show an interest in approaching CSR practices as a means to achieve a praiseworthy reputation, attract customers concerned with social and environmental issues, as well as respond plausibly to shareholders, if questioned. Oliveira (2013) emphasizes that CSR involves decisions on the part of managers whose interests surpass 
economic or technical ambitions referring to the company. Besides, complying with the law is not enough to being socially and economically responsible; one must go beyond the legal minimum.

Commitment to CSR practices may help companies establish partnerships with and gain the trust of different audiences, as well as strengthen their market positions, contributing to the achievement of sustainable competitive advantages (Miron, Pectu, \& Sobolevschi, 2011). Following this line of thought, Feitosa et al. (2014) advocate that, by developing socially and environmentally responsible practices, companies manage to meet those demands whilst acquiring considerable financial performance.

To the extent that economic growth and the achievement of competitive advantages align with environmental preservation and social support measures, one can note it is possible to associate financial performance with social welfare, provided that the (formal or informal) agreement celebrated between parties is balanced (European Comission, 2002). However, Vilanova et al. (2009) highlight that financial performance does not necessarily entail competitiveness in the long run, since the relationship between CSR practices and competitiveness is not as yet totally clear due to a lack of studies of the subject.

\subsection{Influence of responsible practices geared towards stakeholder employees on financial performance}

Companies acquire more value when they manage to raise the price their consumers are willing to pay for their products and services, or when they reduce their production costs. Harrison \& Wicks (2013) support that companies that satisfy the interests of a considerable group of stakeholders will be able to allocate more value to the organization in the long run. Bosse, Phillips \& Harrison (2009) argue that companies that pay fair remuneration to their employees manage to add value to the company thanks to the positive reciprocal response on the part of employees.

According to Mitchell, Agle \& Wood (1997), employees are perhaps the companies' most important stakeholders, because of the potential impact they might have on companies' performance. Accordingly, numerous studies reveal a positive relationship between CSR practices geared towards employees and financial performance (Freeman et al., 2010; Vilanova, et al., 2009). Managers must know how to use socially and environmentally responsible practices in their employees' sphere in order to inspire them to achieve the company's purposes: profitability, growth, and stability (Donaldson \& Preston, 1995).

In this context, employees are influential stakeholders in the organization; therefore, it is necessary to develop these human assets so that they may aggregate value to the company. Such a development also entails consideration for their aspirations during the decision-making process, as well as the establishment of an agreeable organizational atmosphere for work (Leal, Martin, \& Maçal, 2007). Among the benefits of the maintenance of an ethical atmosphere, Sims \& Keon (1997) highlight an improvement in institutions' credibility, an increase in commitment, and a lower level of absenteeism and turnover, which may promote an increase in productivity.

Advantages can go beyond financial benefits. Freeman et al. (2010) indicate the possibility of developing unique resources as a possible benefit of a good relationship with employees, leading companies to achieve competitive advantages. Therefore, a good relationship with employees, since it is an intangible resource, is a factor that competitors will scarcely be able to imitate, thus naturally resulting in competitive advantages.

Corporate social responsibility geared towards employees is approached here based on people management practices (Freitas, Souza, Teixeira, \& Jabbour, 2013), which indicate the relationship between banks and their employees according to the economic, social and organizational profile categories in the Global Reporting Initiative (GRI), and which banks whose shares are negotiated in BM\&FBovespa are obliged to publish: outsourcing (G4-10); economic value distributed to employees as 
remuneration and benefits (G4-E1); turnover (G4-LA1); benefits granted (G4-LA2 e G4LA10), and percentage of women who participate in management and governance departments (G4-LA12).

Outsourcing is usually associated with the rationalization of workforce costs and precarious working conditions (Patrus, Dantas \& Shigaki, 2013). These conditions may cause discomfort because of the disparity between a company's own employees and outsourced workers with regard to salaries and benefits, as well as a reduction of the company's responsibility geared towards outsourced workers, subjecting them to precarious working conditions (Repullo, 1997; Segnini, 1999). Accordingly, outsourcing may deteriorate the relationship between a company and its workforce, which can have a negative impact on employees' productivity, thus negatively and indirectly influencing financial performance. Based on the foregoing argumentation, we formulated this paper's first hypothesis:

H1: Outsourcing has a negative influence on the financial performance of Brazilian banks.

Remuneration and benefits constitute expenses with staff and they have been used as a proxy of companies' social responsibility geared towards employees (Crisóstomo et al., 2011; Machado, Machado, \& Santos, 2010), thus increasing productivity and, consequently, financial performance. Moreover, variable remuneration and profit sharing are features of the Brazilian banking sector that favor a positive relationship between expenses with remuneration and financial performance. Therefore, the second hypothesis tests the relationship between remuneration and performance.

H2: Expenses with employees' remuneration have a positive influence on the financial performance of Brazilian banks.

High turnover rates, both voluntary and involuntary, suggest a bad relationship between companies and their employees. Resignations indicate employees' dissatisfaction with working conditions, and/or job offers that present better working conditions. Dismissals lead to insecurity among employees facing job instability. In addition, turnover reduces employees' productivity through the loss of human capital (Shaw, Gupta, \& Delery, 2005) and increases costs with dismissals, recruitment and training, which can have a negative impact on financial performance (Cardoso, Cardoso, \& Santos, 2013; Glebbeek $\&$ Bax, 2004).

Based on the value-creation perspective, Tantalo \& Priem (2016) argue that stakeholders take into account the value they receive when deciding if they should stay or not in a company, and to what degree of commitment they should carry out their tasks in the workplace, thus interfering in turnover rates. Thus, the third hypothesis involves the relationship between turnover and performance.

H3: Turnover has a negative influence on the financial performance of Brazilian banks.

Women's participation in management and governance departments is associated with opportunity and diversity. Greater women's representativeness in the main corporate positions suggests that a bank aims to reduce gender discrimination. Richard (2000) supports the effect of a stronger perception of justice when companies give women more opportunities to establish themselves at the head of a corporation. Once perceived, this justice, in turn, is seen as a vector in employees' productivity, which can have a positive effect on financial performance. It was the basis for the formulation of the fourth research hypothesis:

H4: Women's participation in management and governance departments has a positive influence on the financial performance of Brazilian banks.

Although the provision of benefits represents a direct increase in costs, its indirect 
impact on performance may be positive. Benefits may have an influence on employees' behavior, reducing risks related to work and increasing the perception of justice (Oliveira \& Leone, 2008). Accordingly the provision of a greater number of benefits may increase employees' productivity, which will have a positive effect on the performance of Brazilian banks, and this was the basis for the formulation of our last research hypothesis:

H5: The total amount of benefits employees are provided with has a positive influence on the financial performance of Brazilian banks.

In a nutshell, this research starts with the assumption that value allocation to stakeholder employees through the adoption of socially responsible practices would increase employees' satisfaction, motivation and commitment, thus having a positive effect on productivity (Arthur, 1994; Blundell, Dearden, Meghir, \& Sianesi, 1999; Bontis \& Fitz-Enz, 2002; Huselid, 1995). Employees' productivity, in turn, either reduces expenses with staff or increases income, which has a positive effect on financial performance (Athanasoglou, Brissimis, \& Delis, 2008).

\section{Methods}

This research adopts a descriptive, documental and quantitative approach. Its sample comprises 21 banks whose shares are negotiated at BM\&FBovespa, which represents $15.4 \%$ of a universe composed of 136 operative banking institutions in Brazil in 2014, aside credit unions (Banco Central do Brasil, 2016). In terms of assets, it represents $51.6 \%$ of all Brazilian banking institutions. In total, the sample consists of 105 observations during a five-year period, between 2010 and 2014.

By using the software called $\mathrm{G}^{*}$ Power 3.1.9.2, it became evident that the size of this sample (105 observations) was convenient to validate results obtained through regression analysis regarding the coefficient of independent variables (Faul, Erdfelder, Buchner \& Lang, 2009). In order to achieve this, we calculated the smallest sample size necessary, so that coefficients of $7 / 8$ predictors could produce an effect size $\mathrm{f}^{2}=$ 0.15 (average/medium), with probability of type I error $\alpha=0.05$ and power $1-\beta=0.95$. The smallest sample size necessary for these parameters consists of 74 observations. As a complement, post hoc tests indicated that the power of all estimations (when processed in ordinary least squares) is higher than 0.98 , considering a type I error $\alpha=0.05$, and the effect size varies from 0.12 to 1.26 .

Companies listed in BM\&FBovespa were chosen because of their great amount of available non-accounting data. For analysis purposes, consolidated data collected from databases available on the websites of Banco Central do Brasil (BCB) and Comissão de Valores Mobiliários (CVM) were considered. Banks that published sustainability reports or the like over that period had their non-financial information checked in those reports.

\section{I Measurement of the variables under study}

Table 1 shows the proxies of the variables in this study and their respective sources. To the variables regarding competitiveness and internal social responsibility were added, as variables of control, the size of the banks, validated with their total assets, and a dummy variable, which indicates whether the bank is under public or private control. Employees' productivity was included in the analyses since it is the variable that reflects a higher degree of employees' commitment to the institution, according to literature (Huselid, 1995), as well as a vector of financial performance (Naceur \& Goaied, 2001), which was the proxy of competitiveness adopted here.

Analysis of competitiveness was carried out through both a qualitative metric (competitive position) and a quantitative metric (competitive performance). Each bank's competitive position (POS_COMP) was processed according to the study by Brito \& Brito (2012), by building a $3 \times 3$ matrix of the combined performance in sales 
growth and ROA. Considering the five years under analysis, an income growth indicator, based on the compound tax of annual growth, and a ROA indicator, the annual average for the period, were calculated for each bank.

Next, the 21 banks in the sample were classified in three groups as to each indicator, according to the $t$ test, for differences in average, with 5\% significance: above average, average, below average. The competitiveness matrix by Brito \& Brito (2012) splits the sample in nine squares, according to each bank's classification regarding sales growth and ROA. The analysis of this matrix, as shown in Figure 1 (which is discussed in the results section), enabled the classification of banks in three groups as to their competitiveness: competitive advantage, competitive parity, and competitive disadvantage. Competitive performance (COMPET) was validated with the arithmetic mean of the gauged scores in the distribution $z$ of income growth and ROA.

Internal CSR and employees' productivity data were gathered from documents available on CVM's and the banks' websites. Outsourcing (TERC) was measured by calculating the ratio of the number of outsourced workers to the total workforce in a bank (outsourced workers and employees who were hired directly), numbers available on the reference form. Remuneration (REMUN) was validated by calculating the ration of the distributed value to the number of employees. These data were gathered from the statement of added value and the reference form, respectively. The turnover represents the ratio of the average number of admissions and dismissals in a period to the number of employees. These data were directly gathered from each banks' reference form.

Table 1

\section{Description of variables used in study}

\begin{tabular}{|c|c|c|c|}
\hline Construct & Variable & Proxy & Data source \\
\hline \multirow{4}{*}{$\begin{array}{l}\text { Financial Performance } \\
\text { (DESEMP) }\end{array}$} & Return on assets (ROA) & $\frac{\text { Operational profit }}{\text { Total assets }}$ & Income statement and balance sheet \\
\hline & $\begin{array}{c}\text { Revenue Growth (CRESC_ } \\
\text { REC) }\end{array}$ & $\operatorname{Ln}\left(\frac{\text { Revenue }_{t}-\text { Rrevenue }_{t-1}}{\text { Revenue }_{t-1}}\right)$ & Value added statement \\
\hline & $\begin{array}{l}\text { Competitive position } \\
\text { (POS_COMP) }\end{array}$ & $\begin{array}{l}\text { Clusters based on competitive matrix: } \\
\text { 1 - Competitive disadvantage } \\
2 \text { - Competitive parity } \\
3 \text { - Competitive advantage }\end{array}$ & $\begin{array}{c}\text { Income statement, balance sheet and } \\
\text { value added statement }\end{array}$ \\
\hline & $\begin{array}{c}\text { Competitive performance } \\
\text { (COMPET) }\end{array}$ & $Z\left(R O A_{t}\right)+Z\left(C R E S_{-} R E C_{t}\right)$ & $\begin{array}{c}\text { Income statement, balance sheet and } \\
\text { value added statement }\end{array}$ \\
\hline \multirow{5}{*}{$\begin{array}{l}\text { Internal Corporate } \\
\text { Social Responsibility } \\
\text { (RSCI) }\end{array}$} & Outsourcing (TERC) & $\frac{\text { Number of outsourcing }}{t}$ & Reference Form \\
\hline & $\begin{array}{l}\text { Turnover } \\
\text { (TURN) }\end{array}$ & $\begin{array}{l}\text { Variable collected directly representing } \\
\text { the employee turnover rate }\end{array}$ & Reference Form \\
\hline & $\begin{array}{l}\text { Employee remuneration } \\
\text { (REMUN) }\end{array}$ & $\operatorname{Ln}\left(\frac{\text { Remuneration }_{t}}{\text { Work force }_{t}}\right)$ & $\begin{array}{l}\text { Value added statement and } \\
\text { Reference Form }\end{array}$ \\
\hline & $\begin{array}{c}\text { Woman's participation in } \\
\text { governance and management } \\
\text { (PFGG) }\end{array}$ & $\frac{\text { Woman Members }_{t}}{\text { Total of members } s_{t}}$ & Reference Form \\
\hline & Benefits provided (BENEF) & $\frac{\text { Benefits provided }_{t}}{\text { Benefits analized }_{t}}$ & $\begin{array}{c}\text { Reference Form and sustainability } \\
\text { report }\end{array}$ \\
\hline
\end{tabular}




\begin{tabular}{|c|c|c|c|}
\hline Construct & Variable & Proxy & Data source \\
\hline $\begin{array}{l}\text { Employee } \\
\text { productivity } \\
\text { (PRODUT) }\end{array}$ & $\begin{array}{l}\text { Employee productivity } \\
\text { (PRODUT) }\end{array}$ & $\operatorname{Ln}\left(\frac{\text { Riqueza gerada }_{t}}{\text { Work } \text { force }_{t}}\right)$ & $\begin{array}{c}\text { Value added statement and } \\
\text { Reference Form }\end{array}$ \\
\hline \multirow[b]{2}{*}{$\begin{array}{l}\text { Control variables } \\
\text { (CONTR) }\end{array}$} & $\begin{array}{l}\text { Size } \\
(\mathrm{TAM})\end{array}$ & Ln(Total assets $\left.{ }_{t}\right)$ & Balance sheet \\
\hline & $\begin{array}{c}\text { Control type } \\
\text { (CONTR_PUBL) }\end{array}$ & $\begin{array}{l}\text { Dummy variable that has value } 1 \text { if } \\
\text { the bank has public control and } 0 \text { has } \\
\text { private control }\end{array}$ & Central Bank of Brazil \\
\hline
\end{tabular}

Women's participation in management and governance departments (PFGG) was estimated according to the percentage of female members in the body of executive directors, board of directors, and auditing committee. This data is available in the reference form. The benefits policy (BENEF) was validated with the amount of benefits voluntarily provided by the bank, as well as those included in the collective bargaining agreement for the category. Initially, we analyzed each bank's benefits policy, available in their reference form, and the benefits provided by the banks that make their sustainability report available on their website.

From this analysis, a list of the ten most recurrent benefits was established: health care programs, dental assistance programs, medical assistance programs, psychological and social assistance programs, life insurance, educational assistance programs, financial social assistance, loans with special conditions when necessary, financial services with special charges, and private pension plans. Afterwards, we ascertained which benefits are reported by each bank. The ratio of the total of benefits analyzed (10) to the number of benefits provided by each bank represents the variable under study, which varies from 0 to 1 .

Employees' productivity was analyzed through the ratio of the wealth created by the bank to its workforce (number of outsourced workers and employees who were hired directly), data which were gathered from the statement of added value and the reference form, respectively. Variables indicative of productivity, expenses with remuneration, and the size of banks were presented as natural logarithm of the original proxies due to the wide data range, which might have impaired the statistical analysis through the presence of outliers. The use of the natural logarithm reduces the data range width and the effect of extreme values, thus preserving the hierarchy of original data.

\subsection{Analysis of the relationship between CSR practices geared towards stakeholder employees and competitiveness}

Two statistical analyses of the association between the competitiveness proxies and the variables that indicate internal social responsibility were carried out: the Jonckheere-Terpstra test, and the regression analysis with the Feasible Generalized Least Squares (FGLS) model. The Jonckheere-Terpstra test aims to identify tendencies in metric variables among groups ordered in ordinal scale.

The groups of companies in positions of competitive disadvantage, competitive parity, and competitive advantage - which are the results in the competitiveness matrix by Brito $\&$ Brito (2012) - were compared regarding the five metric variables indicative of the banks' internal CSR and the variable indicative of employees' productivity, through the Jonckheere-Terpstra test. The statistical significance points to the existence of association tendencies between the groups and the metric variables, while the sign of the test statistic indicates the direction of the association (whether positive or negative).

The FGLS model is recommended for mitigating heteroscedasticity effects and autocorrelation of residuals present in regression analysis with panel data. Initially, all independent 
metric variables were gauged according to their year, in order to indicate each bank's position in relation to its competitors. Subsequently, estimations in FGLS were processed, according to Equations 1 and 2.

$$
\begin{aligned}
& \operatorname{DESEMP}_{i, t}=\alpha+\beta_{1} \operatorname{RSCI}_{i, t}+\beta_{2} \operatorname{CONTR}_{i, j}+\varepsilon \\
& \operatorname{DESEMP}_{i, t}=\alpha+\beta_{1} \operatorname{PRODUT}_{i, t}+\beta_{2} \operatorname{RSCI}_{i, t}+\beta_{3} \operatorname{CONTR}_{i, j}+\varepsilon
\end{aligned}
$$

In which:

$D_{E S E M P}{ }_{i, t}$ represents the financial performance of bank $i$ over period $j$;

$R S C I_{i, j}$ are the variables indicative of the social responsibility of bank $i$ over period $j$ geared towards its employees;

PRODUT $T_{i, j}$ indicates the productivity of employees $i$ over period $j$;

CONTR $_{i, j}$ are the control variables included in the models.

Equation (1) aims to measure the direct effect of internal CSR practices on performance, which is the banks' competitiveness proxy. Equation (2) adds employees' productivity to Equation 1 in order to ascertain if this variable explains the competitive advantage of the banks under analysis and alters the relationship between the variables of the initial models, which would indicate that employees' productivity is a vector that connects internal CSR practices with financial performance.

The presentation of results is based on descriptive statistic, and is followed by the statistical analyses carried out through the Jonckheere-Terpstra test and the FGLS estimations. Finally, we present the validation of the hypotheses of this study, according to its results.

\section{Results}

Table 1 shows the descriptive statistic of the variables used in this paper. The variables TERC, TURN, PFGG, BENEF, CRESC_REC, and ROA are expressed in percentage. The variables REMUN, PRODUT, and TAM are presented through the natural logarithm of their original values. The variable COMPET is the arithmetical mean of the gauged scores of the variables CRESC_REC and ROA. The greatest variances involve the two variables of financial performance. The other ones show a coefficient of variation inferior to the unit.

Table 2

\begin{tabular}{|c|c|c|c|c|c|}
\hline Metrics variables & Minimum & Maximum & Average & $\begin{array}{l}\text { Standard } \\
\text { deviation }\end{array}$ & Coefficient of variation \\
\hline TERC & 0.000 & 0.596 & 0.190 & 0.129 & 0.682 \\
\hline TURN & 0.020 & 0.490 & 0.122 & 0.105 & 0.863 \\
\hline REMUN & 10.660 & 13.952 & 11.632 & 0.569 & 0.049 \\
\hline PFGG & 0.000 & 0.385 & 0.084 & 0.069 & 0.826 \\
\hline BENEF & 0.200 & 0.800 & 0.486 & 0.204 & 0.420 \\
\hline PRODUT & 9.901 & 15.146 & 12.852 & 0.914 & 0.071 \\
\hline CRESC_REC & -0.027 & 0.042 & 0.006 & 0.010 & 1.725 \\
\hline ROA & -0.062 & 0.036 & 0.010 & 0.012 & 1.102 \\
\hline COMPET & -4.382 & 1.602 & 0.000 & 0.832 & - \\
\hline TAM & 21.426 & 27.704 & 23.879 & 1.833 & 0.077 \\
\hline
\end{tabular}

\section{Descript statistics}

As to the type of control, eight banks are under public control, out of which four are federal banks, and four are state banks. The other banks are controlled by private entities. The average of annual income growth in the sample is $0.6 \%$, and the average of profitability is $1 \%$. 


\section{I Association of the clusters of CSR practices geared towards stakeholder employees and competitiveness}

Following the methodology proposed by Brito \& Brito (2012), the banks under study were initially classified according to their financial performance in terms of income growth and return over assets, data that was used in order to establish each bank's position as to competitiveness over the 2010-2014 period. Banks classified under "competitive parity" present income growth and ROA indicators within the average. Banks that did not show superior performance in any of the two indicators, or showed performance below average in at least one of them, are classified under "competitive disadvantage". Banks with "focus on growth" or "focus on profitability" are those above average in one of the indicators and below average in the other. Banks that show performance above average in at least one of the indicators analyzed, and average performance in the other, were classified under "competitive advantage".

The result of the competitiveness matrix can be seen in Figure 1. The clusters of competitive position are based on the $t$ test for differences in average for one sample, with significance of 5\%. The most external squares in income growth and return over assets indicate performance statistically superior to the sample average. Squares in the middle indicate performance statistically equal to the sample average, and squares near the straight line indicate performance statistically inferior to the sample average. Values in brackets indicate the arithmetical mean of the indicator regarding banks classified in each cluster.

One can notice that the sample was equally divided, in the end, with seven banks classified in a position of competitive advantage, seven in a position of competitive parity, and seven in competitive disadvantage. None of the banks in the sample was focused on profitability or growth.

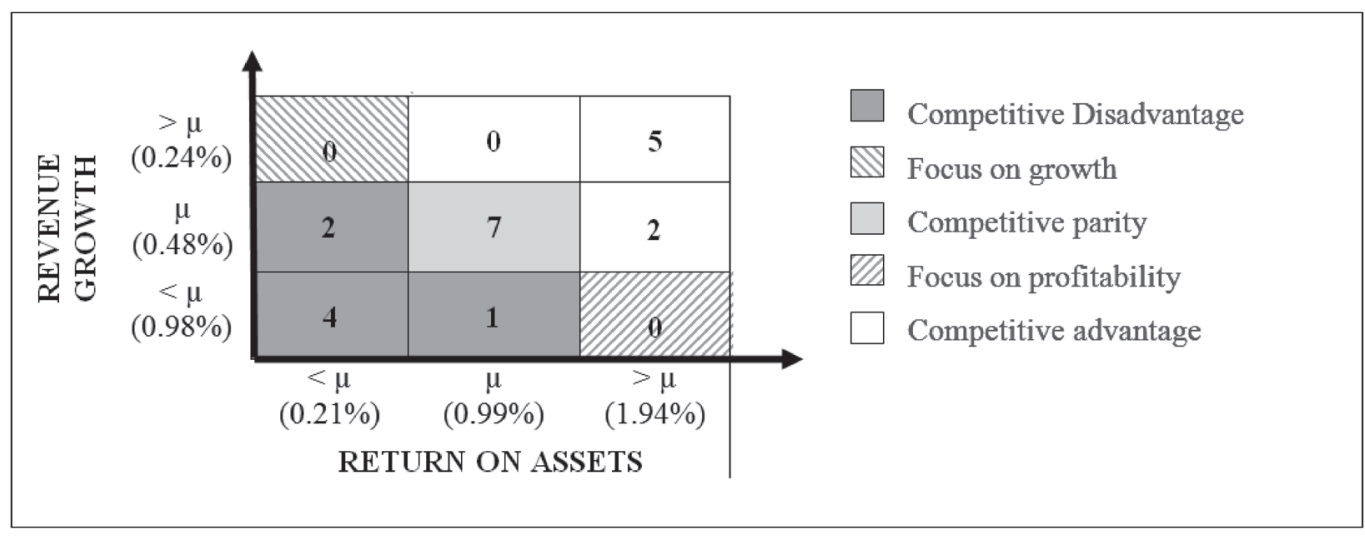

Figure 1. Competitive matrix of analyzed banks

Source: Adapted from "Vantagem competitiva e sua relação com o desempenho-uma abordagem baseada em valor" by R. P. Brito and A. M. Brito, 2012, RAC-Revista de Administração Contemporânea, 16, 360-380.

Table 3 presents analysis of the averages of variables that indicate internal CSR in relation to the competitive position of the banks that make up this sample. The Jonckheere-Terpstra test indicated a positive association of the competitive position with the variable PFGG, and a negative one with TURN, REMUN e BEF_CONC. The variable TERC did not reveal any significant associations.
Joint analysis of the test statistics and averages reveals that banks in a position of competitive disadvantage tend to show higher turnover rates (19.04\%). To the same effect, banks in a position of competitive advantage provide fewer benefits than the others (37.14\%). With smaller significance, one observes that banks with a higher level of women's participation in the top management and governance tend to be more competitive. 
As to the wealth distributed as remuneration, although it shows a negative statistic, and with significance of $10 \%$, it reveals a peculiar behavior in relation to the clusters of competitive position. Banks in a position of competitive advantage are the ones that pay better remunerations to their employees (approximately
R\$ 200,000.00 per employee/year). However, banks in a position of competitive disadvantage distribute, on average, much more wealth to their employees by way of remuneration than banks that are in a position of competitive parity (approximately $\mathrm{R} \$ 131,000.00$ and $\mathrm{R} \$ 98,000.00$ per employee/year, respectively).

Table 3

\section{RSC practices directed to stakeholder employees for competitive position}

\begin{tabular}{lcccccc}
\hline \multirow{2}{*}{$\begin{array}{l}\text { RSC practices directed to } \\
\text { the employee }\end{array}$} & \multicolumn{2}{c}{ Competitive } & \multicolumn{2}{c}{ Jonckheere-Terpstra } \\
\cline { 2 - 5 } test
\end{tabular}

Note. ${ }^{*},{ }^{* *}$ and ${ }^{* * *}$ indicate statistical significance of $10 \%, 5 \%$ e $1 \%$, respectively.

\subsection{The relationship between CSR practices geared towards stakeholder employees and competitiveness}

Table 3 shows the correlations between metric variables used in the estimations. It reveals a positive correlation between the variable of employees' productivity (PRODUT) and the three variables indicative of performance. As to
CSR practices geared towards employees, one can notice a negative correlation between turnover and the number of benefits, and a positive correlation between women's participation in management and governance departments and both profitability and competitive performance. There was no significant correlation between both outsourcing and remuneration and any of the variables of performance.

Table 4

\section{Correlation between standard metric variables per year}

\begin{tabular}{|c|c|c|c|c|c|c|c|c|c|c|}
\hline & \multicolumn{2}{|c|}{ TERC } & \multicolumn{2}{|l|}{ TURN } & \multicolumn{2}{|c|}{ REMUN } & \multicolumn{2}{|l|}{ PFGG } & \multicolumn{2}{|l|}{ BENEF } \\
\hline TERC & 1.000 & & & & & & & & & \\
\hline TURN & -0.271 & $* * *$ & 1.000 & & & & & & & \\
\hline REMUN & -0.296 & $* * *$ & 0.362 & $* * *$ & 1.000 & & & & & \\
\hline PFGG & 0.351 & $* * *$ & -0.314 & $* * *$ & -0.460 & $* * *$ & 1.000 & & & \\
\hline BENEF & 0.250 & $* *$ & -0.132 & & -0.383 & $* * *$ & -0.167 & * & 1.000 & \\
\hline PRODUT & -0.510 & $* * *$ & 0.174 & * & 0.602 & $* * *$ & -0.319 & $* * *$ & -0.354 & $* * *$ \\
\hline CRES_REC & -0.054 & & -0.137 & & 0.112 & & 0.076 & & -0.103 & \\
\hline ROA & -0.098 & & -0.260 & $* * *$ & -0.011 & & 0.252 & $* * *$ & -0.321 & $* * *$ \\
\hline COMPET & -0.088 & & -0.238 & $* *$ & 0.061 & & 0.197 & $* *$ & -0.245 & $* *$ \\
\hline \multirow[t]{2}{*}{ TAM } & 0.210 & $* *$ & -0.188 & * & -0.033 & & -0.328 & $* * *$ & 0.640 & $* * *$ \\
\hline & \multicolumn{2}{|c|}{ PRODUT } & \multicolumn{2}{|c|}{ CRES_REC } & $\mathrm{ROA}$ & & \multicolumn{2}{|l|}{ COMPET } & TAM & \\
\hline PRODUT & 1.000 & & & & & & & & & \\
\hline CRES_REC & 0.392 & $* * *$ & 1.000 & & & & & & & \\
\hline $\mathrm{ROA}$ & 0.385 & $* * *$ & 0.487 & $* * *$ & 1.000 & & & & & \\
\hline COMPET & 0.451 & $* * *$ & 0.862 & $* * *$ & 0.862 & $* * *$ & 1.000 & & & \\
\hline TAM & 0.024 & & -0.046 & & -0.201 & $* *$ & -0.143 & & 1.000 & \\
\hline
\end{tabular}

Note. ${ }^{*},{ }^{* *}$ and ${ }^{* * *}$ indicate statistical significance of $10 \%, 5 \%$ e $1 \%$, respectively. 
The results of the regression analysis that used both Equation 1 models (models 1, 3 and 5) and Equation 2 models (models 2, 4 and 6) are presented in Table 4. Among the variables of control, the table shows no correlation between TAM and any of the variables of performance; there is a positive correlation between CONTR_ PUBL and both ROA and COMPET, the latter revealing sensitivity to the control of PRODUT. The results found through models 1, 3 and 5, given in Table 4, show that outsourcing has a negative effect on both ROA and competitive performance.

When employees' productivity is included as an independent variable (estimations 2, 4 and 6 in Table 4), it becomes clear that it positively affects financial performance. This positive relationship between productivity and financial performance alters both the coefficient and the significance of outsourcing and remuneration, thus suggesting that these CSR practices towards employees affect financial performance by way of an increase in employees' productivity.

Table 5

Regression analysis with the Feasible Generalized Least Squares (FGLS) model.

\begin{tabular}{|c|c|c|c|c|c|c|c|c|c|c|c|c|}
\hline & \multicolumn{4}{|l|}{ ROA } & \multicolumn{4}{|c|}{ CRESC_REC } & \multicolumn{4}{|c|}{ COMPET } \\
\hline & $(1)$ & & (2) & & (3) & & (4) & & (5) & & (6) & \\
\hline PRODUT & & & 0.650 & $* * *$ & & & 0,630 & $* * *$ & & & 0,640 & *** \\
\hline TERC & -0.289 & $* * *$ & -0.056 & & -0.116 & & 0,109 & & $-0,202$ & ** & 0,027 & \\
\hline TURN & -0.270 & $* *$ & -0.198 & $* *$ & -0.258 & $* *$ & $-0,189$ & * & $-0,264$ & $* * *$ & $-0,194$ & $* *$ \\
\hline REMUN & 0.160 & & -0.103 & & 0.332 & $* * *$ & 0,077 & & 0,246 & $* *$ & $-0,013$ & \\
\hline PFGG & 0.314 & $* * *$ & 0.280 & $* * *$ & 0.226 & $*$ & 0,193 & $*$ & 0,270 & $* * *$ & 0,237 & $* * *$ \\
\hline BENEF & -0.239 & * & -0.053 & & 0.080 & & 0,260 & $* *$ & $-0,079$ & & 0,104 & \\
\hline TAM & 0.091 & & -0.090 & & -0.036 & & $-0,211$ & & 0,027 & & $-0,150$ & \\
\hline CONTR_PUBL & 0.386 & $*$ & 0.562 & $* * *$ & -0.005 & & 0,165 & & 0,190 & & 0,364 & $* *$ \\
\hline Chi-squared & 47.940 & $* * *$ & 105.140 & $* * *$ & 14.000 & $*$ & 43,460 & $* * *$ & 34,050 & $* * *$ & 100,180 & $* * *$ \\
\hline Observations & 105 & & 105 & & 105 & & 105 & & 105 & & 105 & \\
\hline Banks & 21 & & 21 & & 21 & & 21 & & 21 & & 21 & \\
\hline Periods & 5 & & 5 & & 5 & & 5 & & 5 & & 5 & \\
\hline
\end{tabular}

Note. ${ }^{*},{ }^{* *}$ and ${ }^{* * *}$ indicate statistical significance of $10 \%, 5 \%$ e $1 \%$, respectively.

Chart 2 shows the research findings and the hypothesis considered here, and it takes into account the results of the statistic tests with a significance of $5 \%$. Findings confirm hypothesis $\mathrm{H}_{1}$, suggesting that the hire of outsourced workers has a negative impact on the profitability of Brazilian banks. Hypothesis $\mathrm{H}_{2}$ is also confirmed, indicating that turnover is associated with banks' competitive positions. The correlation between turnover and the three performance indicators analyzed here is negative, and the same applies to the correlation between turnover and competitive position.
Results confirm hypothesis $\mathrm{H}_{3}$ and show that remuneration is a vector in the sales growth and competitive performance of banks. Research also confirmed hypothesis $\mathrm{H}_{4}$, thus revealing that women's participation in management and governance departments positively affects the financial performance of Brazilian banks. Finally, findings suggest that the number of benefits reduces profitability, which contradicts hypothesis $\mathrm{H}_{5}$. 
Table 6

\section{Hypotheses and research findings}

\begin{tabular}{|c|c|c|c|}
\hline Relationship & Hypotheses & Research findings & Results \\
\hline TERC $\rightarrow$ Competitiveness & $\mathrm{H}_{1}:$ Negative effect & $\begin{array}{l}\text { Negative relationship with ROA and COMPET, mediated } \\
\text { by PRODUT }\end{array}$ & Supported \\
\hline TURN $\rightarrow$ Competitiveness & $\mathrm{H}_{2}$ : Negative effect & $\begin{array}{l}\text { Negative association with POS_COMPET } \\
\text { Negative relationship with ROA, CRESC_REC and } \\
\text { COMPET }\end{array}$ & Supported \\
\hline REMUN $\rightarrow$ Competitiveness & $\mathrm{H}_{3}:$ Positive effect & $\begin{array}{l}\text { Positive relationship with CRESC_REC and COMPET, } \\
\text { mediated by PRODT }\end{array}$ & Supported \\
\hline PFGG $\rightarrow$ Competitiveness & $\mathrm{H}_{4}$ : Positive effect & $\begin{array}{l}\text { Positive relationship with ROA, CRESC_REC and } \\
\text { COMPET }\end{array}$ & Supported \\
\hline BENEF $\rightarrow$ Competitiveness & $\mathrm{H}_{5}$ : Positive effect & $\begin{array}{l}\text { Positive association with POS_COMPET } \\
\text { Negative relationship with ROA and Positive relationship } \\
\text { with CRESC_REC }\end{array}$ & Not supported \\
\hline
\end{tabular}

\section{Discussion}

This research has demonstrated how important it is for the competitiveness of Brazilian banks to allocate value to stakeholder employees through the adoption of CSR practices. Therefore, its results motivate banks to cultivate a better relationship with their employees. This research contributes to the inquiry proposed by Harrison $\&$ Bosse (2013) into the identification of how much value must be allocated to stakeholders. Accordingly, despite the costs of implementing CSR practices, there is value added to companies, which has an effect on competitiveness.

With regard to outsourcing, it became clear that banks in a position of competitive advantage have lower outsourcing rates. Outsourced workers submit to worse working conditions than employees in the banking sector, who are supported by the category's collective bargaining agreement. In the long run, the lack of essential working conditions may be a cause for the association of outsourcing with financial performance. Furthermore, it is discernible that employees' productivity is a mediatory variable, strengthening the idea that high outsourcing rates in the banking sector lead to dissatisfaction and lack of organizational commitment, with an effect on competitiveness due to lower productivity.
Although outsourcing of non-core activities, and even of some core activities (such as check clearance and banking counterparts) is a widespread practice in the Brazilian banking sector as a means of reducing costs, it is usually accompanied by an increasing precariousness of working conditions, as advocates Segnini (1999). A similar result was identified by Kotabe $\& \mathrm{Mol}$ (2009) in the study of a sample of manufacture companies in the Netherlands between 1995 and 1998, and which investigated how outsourcing could affect financial performance. In all activities of the companies in the sample, the degree of outsourcing had a negative influence on financial performance.

Turnover, in turn, proved to generate costs that reduce financial performance - expenses with dismissals, admissions, and training. Similarly, Glebbeek \& Bax (2004) tested the hypothesis that turnover influences companies' performance and discovered a function in the form of an upsidedown U. In other words, when the turnover rate is extremely high or low, financial performance is negatively affected. In another study, carried out in Brazil, Cardoso et al. (2013) noticed that turnover and absenteeism have a negative impact on sales income, and consequently on financial performance. Thus, there are negative correlations between performance indicators and high turnover rates. 
This research revealed that banks in a position of competitive advantage have greater expenses with remuneration. Endogeneity between productivity and remuneration, however, has to be taken into account, since the collective bargaining agreement for the banking sector prescribes variable remunerations and profit sharing. The theoretical argument that higher remuneration can reduce financial performance was not verified, which indicates that gains deriving from productivity as a result of higher remuneration surpass the negative impact of the latter on ROA.

Similar results were obtained by Bloom (1999), who tried to understand the relationship between companies' policies on employees' remuneration and their performance. Field research carried out with 1,644 baseball players in 29 different teams suggests that the more a company invests in its employees' remuneration, the higher its performance. Attractive remuneration can appeal to and maintain the best professionals in a certain field, who in turn use their skills so as to provide the company with competitive advantage.

Another research finding confirms the hypothesis that women's participation in management and governance departments has an influence on the competitiveness of Brazilian banks. However, this relationship has nothing to do with employees' productivity, as was the argument in the theoretical reference. These findings still call for more empirical evidence and theoretical discussion, but a possible explanation for them could be the higher value allocated by women in management positions, as well as the fact that they remain within an organizational environment which is still predominantly male. Descriptive statistic shows that women represent only $8.3 \%$ of the management and governance departments of the banks in the sample.

This result is aligned with the findings by Richard (2000), who carried out research on the impact of women's inclusion in the American banking sector. The more a company promotes the inclusion of female employees in its hierarchical levels, the more it adds value to the organization, thus gaining a position of competitive advantage in comparison to other companies in the same sector.

Another study, which was carried out by Campbell \& Vera (2009), reveals that, after appointing women to management positions, there was an increase in prices of companies' shares in Spain. In the short run, the stock market reacts positively to the announcement of such nominations. In the long run, the appointment of women to boards of directors is also positively associated with the companies' value. This result suggests that investors believe female directors aggregate value to organizations.

Benefits policy in turn, measured by the number of benefits provided by companies, was the only CSR practice geared towards stakeholder employees that proved not to have any relationship with competitiveness. On the contrary, one can notice that the profitability of banks is negatively affected when employees are conferred more benefits. The competitive position analysis (Table 2) reinforces the hypothesis that the number of benefits does not bring about competitive advantage. Contrarily, costs with benefits reduce banking financial performance.

This result resonates with the research carried out by Huselid et al. (1997), who analyzed the effect that investment in human resources practices had on the financial performance of 293 American organizations. They identified a slightly positive relationship between the provision of benefits and financial performance. It is their belief that, as benefits are already institutionalized, employees do not realize the impact of such increments, which would not have an effect on the competitiveness of companies.

This research confirms the arguments proposed by Bosse et al. (2009), according to whom companies incur in costs in order to be seen as fair. However, employees are considered key stakeholders in the process of creating value. Our research findings are also aligned with the framework proposed by Tantalo \& Priem (2016) 
on how much value companies should allocate to their stakeholders. Competitive companies stop allocating value to stakeholders based on their own reciprocity principle.

Harter Schmidt \& Hayes (2002) carried out a study in 7,939 business units in 36 companies in order to analyze how the relationship employeeemployer could furnish satisfaction, commitment and positive financial results. These gains establish what Harrison \& Wicks (2013) define as a "value-creation system", a situation in which each interested party provides resources or influence so as to receive some material and/or intangible asset in return. The result is an allocation of value from which all of the company's stakeholders benefit.

\section{Conclusion}

This study confirms that the allocation of value to stakeholder employees, especially in the Brazilian banking sector, has a positive effect on competitiveness. Its findings indicate that low turnover rates and greater women's participation in management and governance departments positively influence the competitiveness of the banks under analysis. Although women make up a good deal of banks' workforce, their participation in top management positions is still proportionally small. Besides, low outsourcing rates and more expenses with remuneration contribute to competitiveness thanks to their impact on productivity. However, there seems to be a limit for the allocation of value when it comes to the total number of benefits. This limit is based on the principle of reciprocity: employees' perception, and that which can be transformed into an increase in competitiveness.

In the theoretical field, this paper contributes to the discussion based on the instrumental view of the stakeholder theory, by strengthening the causality relationship between corporate financial and social performances. In fact, this study highlights the strategic role of people management policies focused not only on costs reduction, but also on the adoption of socially responsible practices in order to achieve competitive advantages. The peculiarities of the banking sector, which involve direct contact between employees and customers when rendering services, emphasize the importance of banks maintaining a good relationship with their employees in order to ensure their satisfaction and commitment, resulting in an increase in productivity and financial performance.

However, this study also has its limitations. The sample exclusively made up of banks whose shares are negotiated at BM\&FBovespa prevents us from generalizing its results. CSR was analyzed only through practices published by the banks themselves, with the exclusion of other relevant practices that could have a positive or negative effect on financial performance. Being a latent construct, competitiveness cannot be directly studied; it can only be studied through organizational outputs.

Future research could use a sample that is more representative of the Brazilian banking sector, as well as analyze the relationship between CSR practices geared towards employees and the competitiveness of companies in other institutional environments. Deeper studies with primary data may identify a greater number of CSR practices, thus enabling a more precisely assessment of their role as source of competitive advantage. Finally, we suggest the use of more sophisticated statistical methods to measure causality relationships with a lower margin of error, such as models of simultaneous equations and generalized models of moments.

\section{References}

Ajitabh, A., \& Momaya, K. S. (2004). Competitiveness of firms: review of theory, frameworks and models. Singapore management review, 26(1), 45-61.

Arthur, J. B. (1994). Effects of human resource systems on manufacturing performance and turnover. Academy of Management journal, 37(3), 670-687. 
Athanasoglou, P. P., Brissimis, S. N., \& Delis, M. D. (2008). Bank-specific, industry-specific and macroeconomic determinants of bank profitability. Journal of international financial Markets, Institutions and Money, 18(2), 121-136.

Banco Central do Brasil (2016). Relação de instituiçôes bancárias atuantes no Brasil. Recuperado de http://www.bcb.gov.br.

Barney, J. B. (2000). Firm resources and sustained competitive advantage. Advances in Strategic Management, 17(1), 203-227.

Bartel, A. P. (2004). Human resource management and organizational performance: Evidence from retail banking. Industrial \& Labor Relations Review, 57(2), 181-203.

Bloom, M. (1999). The performance effects of pay dispersion on individuals and organizations. Academy of Management Journal, 42(1), 2540.

Blundell, R., Dearden, L., Meghir, C., \& Sianesi, B. (1999). Human capital investment: the returns from education and training to the individual, the firm and the economy. Fiscal studies, 2O(1), 1-23.

Boaventura, J. M. G. (2012). Dominância de stakeholders em empresas brasileiras: contribuiçóes à teoria dos stakeholders (Tese de livre docência). Universidade de São Paulo.

Bontis, N., \& Fitz-Enz, J. (2002). Intellectual capital ROI: a causal map of human capital antecedents and consequents. Journal of Intellectual capital, 3(3), 223-247.

Bosse, D. A.; Phillips, R.A. \& Harrison, J.S. (2009). Stakeholders, reciprocity, and firm performance. Strategic Management Journal, 30, 447-456.

Brito, R. P., \& Brito, L. A. L. (2012). Vantagem competitiva e sua relação com o desempenho- uma abordagem baseada em valor. $R A C$ Revista de Administração Contemporânea, 16(3), 360-380.

Campbell, K., \& Vera, A. M. (2010). Female board appointments and firm valuation: Short and long-term effects. Journal of Management \& Governance, 14(1), 37-59.

Cardoso, M. F., Freitas C. J., \& Santos, S. R. (2013). O impacto da rotatividade e do absenteísmo de pessoal sobre o custo do produto: um estudo em uma indústria gaúcha. Revista de Gestão, Finanças e Contabilidade, 3(1), 107.

Carroll, A. B. (1979). A three-dimensional conceptual model of corporate performance. Academy of management review, 4(4), 497505.

Crisóstomo, V. L., Freire, F. S., \& Vasconcellos, F. C. (2011). Corporate social responsibility, firm value and financial performance in Brazil. Social Responsibility Journal, 7(2), 295-309.

Donaldson, T., \& Dunfee, T. W. (2002). Ties that bind in business ethics: Social contracts and why they matter. Journal of Banking \& Finance, 26(9), 1853-1865.

Donaldson, T., \& Preston, L. E. (1995). The stakeholder theory of the corporation: Concepts, evidence, and implications. Academy of management Review, 20(1), 6591.

Elkington, J. (1998), Cannibals with Forks: The Triple Bottom Line of 21 st Century Business. New Society Publishers.

European Commission (2002). DirectorateGeneral for Employment, \& Social Affairs. Unit D. Corporate Social Responsibility: A business contribution to sustainable development. Office for Official Publications of the European Communities. 
Faul, F., Erdfelder, E., Buchner, A., \& Lang, A. G. (2009). Statistical power analyses using $G^{*}$ Power 3.1: Tests for correlation and regression analyses. Behavior research methods, 41(4), 1149-1160.

Feitosa, M. J. S., de Souza, N. M. O., \& Gómez, C. R. P. (2014). Princípios da responsabilidade social empresarial nas relaçôes "empresa-stakeholders" como fonte de vantagem competitiva. REUNIR: Revista de Administração, Contabilidade e Sustentabilidade, 4(1), 42-61.

Freeman, R. E. (1984). Strategic Management: A Stakeholder Approach. Boston: Pitman Publishing.

Freeman, R. E., \& Evan, W. M. (1990). Corporate governance: A stakeholder interpretation. Journal of Behavioral Economics, 19(4), 337-359.

Freeman, R. E., Harrison, J. S., Wicks, A. C., Parmar, B. L., \& Colle, S. (2010). Stakeholder theory: The state of the art. Cambridge University Press.

Freitas, W. R. S., Souza, M. T. S., Teixeira, A. A., \& Jabbour, C. J. C. (2013). Produção científica sobre gestão de recursos humanos e sustentabilidade: síntese e agenda de pesquisa. Revista de Ciências da Administração, 15(36), 11.

Garcia-Castro, R., \& Aguilera, R. V. (2015). Incremental value creation and appropriation in a world with multiple stakeholders. Strategic Management Journal, 36, 137-147.

Glebbeek, A. C., \& Bax, E. H. (2004). Is high employee turnover really harmful? An empirical test using company records. Academy of Management Journal, 47(2), 277-286.

Hamel, G., \& Prahalad, C.K. (1989). Strategic intent. Harvard Business Review, 3. Edition.
Harrison, J.S., \& Bosse, A. D. (2013). How much is too much? The limits to generous treatment of stakeholders. Business Horizons, 56, 313-322.

Harrison, J. S., Freeman, R. E., \& Abreu, M. C. S. (2015). Stakeholder Theory as an Ethical Approach to Effective Management: applying the theory to multiple contexts. Revista Brasileira de Gestão de Negócios, 17(55), 858.

Harrison, J. S., \& Wicks, A. C. (2013). Stakeholder theory, value, and firm performance. Business ethics quarterly, 23(01), 97-124.

Harter, J. K., Schmidt, F. L., \& Hayes, T. L. (2002). Business-unit-level relationship between employee satisfaction, employee engagement, and business outcomes: a metaanalysis. Journal of applied psychology, 87(2), 268-279.

Huselid, M. A. (1995). The impact of human resource management practices on turnover, productivity, and corporate financial performance. Academy of management journal, 38(3), 635-672.

Huselid, M. A., Jackson, S. E., \& Schuler, R. S. (1997). Technical and strategic human resources management effectiveness as determinants of firm performance. Academy of Management journal, 4O(1), 171-188.

Jones, T. M. (1995). Instrumental stakeholder theory: A synthesis of ethics and economics. Academy of management review, 20(2), 404-437.

Kay, J. (1993). Foundations of corporate success: how business strategies add value. Oxford Paperbacks.

Kotabe, M., \& Mol, M. J. (2009). Outsourcing and financial performance: A negative curvilinear effect. Journal of Purchasing and Supply Management, 15(4), 205-213. 
Leal, C. C., Martin, D. M. L. \& Marçal, E. F. (2007). Desempenho social no âmbito dos empregados e os resultados financeiros das empresas. Rio de Janeiro: XXXI Encontro da ANPAD.

Lozano, J. M. (2002). Towards the Relational Corporation: From Managing Stakeholder Relations to Building Stakeholder Relationships (Waiting for Copernicus), Corporate Governance 5(2), 60-77.

Machado, M. R., Machado, M. A. V., \& Santos, A. (2010). A relação entre setor econômico e investimentos sociais e ambientais. Contabilidade, Gestão e Governança, 13(3).

Maloni, M. J., \& Brown, M. E. (2006). Corporate social responsibility in the supply chain: an application in the food industry. Journal of business ethics, 68(1), 35-52.

Margolis, J. D., \& Walsh, J. P. (2003). Misery loves companies: Rethinking social initiatives by business. Administrative science quarterly, 48(2), 268-305.

Mitchell, R. K., Agle, B. R., \& Wood, D. J. (1997). Toward a theory of stakeholder identification and salience: Defining the principle of who and what really counts. Academy of management review, 22(4), 853886.

Miron, D., Petcu, M., \& Sobolevschi, I. M. (2011). Corporate social responsibility and the sustainable competitive advantage. Amfiteatru Economic, 13(29), 162-179.

Naceur, S. B., \& Goaied, M. (2001). The determinants of the Tunisian deposit banks' performance. Applied Financial Economics, 11(3), 317-319.

Oliveira, J. A. P. (2013). Empresas na sociedade: Sustentabilidade e responsabilidade social (2a ed.). Rio de Janeiro: Elsevier.
Oliveira, P. W. S., \& Leone, R. J. G. (2008). Gestão estrátegica de benefícios: proposição de um modelo matemático para asistência médica dos funcionários. Revista de Administração Mackenzie, 9(2) , 104-127.

Patrus, R., Dantas, D., \& Shigaki, H. (2013). Produtivismo e solidariedade acadêmica: dois lados da mesma moeda. IV Encontro de Ensino e Pesquisa em Administração e Contabilidade (EnEPQ).

Repullo Junior, R. (1997). Os sindicatos, a terceirizaçäo e a saúde dos trabalhadores. Rev. bras. saúde ocup, 23(85/86), 79-82.

Richard, O. C. (2000). Racial diversity, business strategy, and firm performance: A resourcebased view. Academy of management journal, 43(2), 164-177.

Segnini, L. R. P. (1999). Reestruturação nos bancos no Brasil: desemprego, subcontratação e intensificação do trabalho. Educação \& Sociedade, 20(67), 183-209.

Shaw, J. D., Gupta, N., \& Delery, J. E. (2005). Alternative conceptualizations of the relationship between voluntary turnover and organizational performance. Academy of Management Journal, 48(1), 50-68.

Sims, R. L., \& Keon, T. L. (1997). Ethical work climate as a factor in the development of person-organization fit. Journal of Business Ethics, 16(11), 1095-1105.

Solomon, R. C. (1993). Ethics and Excellence. Cooperation and Integrity in Business. Oxford: Oxford University Press.

Swanson, D. L. (1995). Addressing a theoretical problem by reorienting the corporate social performance model. Academy of management review, 20(1), 43-64.

Tantalo, C. \& Priem, R. (2016). Value creation through stakeholder synergy. Strategic Management Journal, 37, 314-329. 
Vilanova, M., Lozano, J. M., \& Arenas, D. (2009). Exploring the nature of the relationship between CSR and competitiveness. Journal of Business Ethics, 87(1), 57-69.

Waddock, S. (2000). The Multiple Bottom Lines of Corporate Citizenship: Social Investing, Reputation, and Responsibility Audits, Business \& Society Review 105(3), 323-346.
Zadek, S. (2006), Responsible Competitiveness: Reshaping Global Markets Through Responsible Business, Corporate Governance: The International Journal of Effective Board Performance 6(4), 334-348.

\section{Supporting agencies:}

CNPq - National Council for Scientific and Technological Development (Project \#446047/2014-7).

FUNCAP - Fundação Cearense de Apoio ao Desenvolvimento Científico e Tecnológico (Scholarship).

\section{About the authors:}

1. Isac de Freitas Brandáo, Phd candidate, Federal University of Ceará. E-mail: isacdefreitas@hotmail.com

2. Andressa Silva Miranda Diógenes, Master in Business, Federal University of Ceará.

E-mail: andressadiogenes@outlook.com

3. Mônica Cavalcanti Sá de Abreu, Doctor in Manufacturing Engineering. E-mail: mabreu@ufc.br

\section{Note:}

A preliminary version of this article was presented on XL Encontro da Anpad - Associação Nacional de PósGraduação e Pesquisa em Administração (Costa do Sauípe - Mata de São João - BA). For this version, the article had update parts.

\section{Contribution of each author:}

\begin{tabular}{lccc}
\hline Contribution & $\begin{array}{c}\text { Isac de Freitas } \\
\text { Brandáo }\end{array}$ & $\begin{array}{c}\text { Andressa Silva } \\
\text { Miranda Diógenes }\end{array}$ & $\begin{array}{c}\text { Mônica Cavalcanti } \\
\text { Sá De Abreu }\end{array}$ \\
\hline $\begin{array}{l}\text { 1. Definition of research problem } \\
\text { 2. Development of hypotheses or research questions } \\
\text { (empirical studies) }\end{array}$ & $\sqrt{ }$ & $\sqrt{ }$ & $\sqrt{ }$ \\
$\begin{array}{l}\text { 3. Development of theoretical propositions } \\
\text { (theoretical Work) }\end{array}$ & $\sqrt{ }$ & $\sqrt{ }$ & $\sqrt{ }$ \\
4. Theoretical foundation / Literature review & & $\sqrt{ }$ \\
5. Definition of methodological procedures & $\sqrt{ }$ & & \\
6. Data collection & $\sqrt{ }$ & $\sqrt{ }$ \\
7. Statistical analysis & $\sqrt{ }$ & & \\
8. Analysis and interpretation of data & $\sqrt{ }$ & $\sqrt{ }$ \\
9. Critical revision of the manuscript & & $\sqrt{ }$ \\
10. Manuscript Writing & $\sqrt{ }$ & \\
\hline
\end{tabular}

